Prosiding Seminar Nasional Teknologi Informasi dan Kedirgantaraan : Transformasi Teknologi untuk Mendukung Ketahanan Nasional, Yogyakarta, 13 Desember 2018

SENATIK 2018, Vol. IV, ISBN 978-602-52742-0-6

DOI: http://dx.doi.org/10.28989/senatik.v4i0.142

\title{
A COMPARATIVE STUDY OF PROBLEM SOLVING METHODS IN DECISION SUPPORT SYSTEMS Obert $^{1)}$, Muhammad Fadlan ${ }^{2)}$ \\ ${ }^{1}$ Program Studi Manajemen Informatika, STMIK PPKIA Tarakanita Rahmawati, Tarakan \\ ${ }^{2}$ Program Studi Sistem Informasi, STMIK PPKIA Tarakanita Rahmawati, Tarakan \\ ${ }^{1,2)}$ Jalan Yos Sudarso No. 8, Tarakan, Kalimantan Utara \\ Email: ${ }^{1}$ obert@ ppkia.ac.id, ${ }^{2}$ fadlan@ppkia.ac.id
}

\begin{abstract}
Decision Support System (DSS) as one of the disciplines related to decision making both by individuals and companies in general, has been widely applied in various fields such as health, education, energy and business. There are several choices of methods related to decision support systems that have been used globally. The selection of suppliers as one of the important agendas in a company requires a decision support system so that the selected supplier is the best according to the criteria set by the company. In this study several DSS methods are used to solve supplier selection problems. In addition, this study conducted a comparison of the three methods in the DSS, namely WSM, SAW and WP in the case of supplier selection. The main contribution of this article is to compare some DSS methods that have not been studied before. As a result, there are two of the three methods that have the same sequence of results, namely the SAW and WP methods. Where in both methods the A2 alternative has the highest value of 0.875 for $S A W$ and 0.84 for WP results. While very different results are obtained using WSM calculations.
\end{abstract}

Keywords : DSS, WSM, WP, SAW, supplier

Abstrak

Sistem Pendukung Keputusan (SPK) sebagai salah satu disiplin ilmu yang terkait dengan pengambilan keputusan baik oleh individu maupun perusahaan pada umumnya, telah banyak diterapkan diberbagai bidang seperti kesehatan, pendidikan, energi dan bisnis. Terdapat beberapa pilihan metode terkait dengan sistem pendukung keputusan yang telah digunakan secara global. Pemilihan pemasok sebagai salah satu agenda penting dalam suatu perusahaan membutuhkan sebuah sistem pendukung keputusan agar pemasok yang terpilih adalah yang terbaik sesuai dengan kriteria yang telah ditetapkan perusahaan. Pada penelitian ini beberapa metode SPK digunakan untuk menyelesaikan permasalahan pemilihan pemasok. Selain itu, penelitian ini melakukan perbandingan dari tiga metode dalam SPK, yaitu WSM, SAW dan WP dalam kasus pemilihan pemasok. Kontribusi utama dari artikel ini adalah melakukan komparasi terhadap beberapa metode SPK yang belum pernah diteliti sebelumnya. Hasilnya, terdapat dua dari tiga metode yang memiliki urutan hasil yang sama yaitu metode SAW dan WP. Dimana pada kedua metode tersebut alternatif A2 memilki nilai tertinggi sebesar 0.875 untuk SAW dan 0.84 untuk hasil WP. Sedangkan hasil yang sangat jauh berbeda didapat dengan menggunakan perhitungan WSM.

Kata kunci: SPK, WSM, WP, SAW, pemasok 


\section{Pendahuluan}

Sistem Pendukung Keputusan (SPK) adalah disiplin untuk mengidentifikasi dan memilih alternatif berdasarkan nilai dan preferensi pembuat keputusan [1]. Pengambilan keputusan merupakan masalah penting bagi perusahaan untuk menemukan alternatif terbaik dari beberapa alternatif [2]. SPK merupakan salah satu cabang keilmuan di bidang kecerdasan buatan yang merupakan bagian dari sistem informasi berbasis komputer [3].

Beberapa penelitian tentang SPK telah dilakukan diberbagai bidang kehidupan diantaranya SPK untuk melakukan pendeteksian dan penilaian kerusakan akibat gempa bumi [4], SPK untuk pemilihan lokasi ladang angin / wind farm [5], SPK dibidang peternakan [6], dibidang kesehatan untuk memprediksi risiko kegagalan jantung [7], SPK dalam bidang pendidikan untuk pemberian beasiswa [8] dan SPK untuk penentuan peserta dalam lomba cerdas cermat [9]. Terdapat beberapa metode dalam SPK yang dapat digunakan, diantaranya metode Weighted Sum Model (WSM) yang terdapat pada penelitian [1], [10], Simple Additive Weighting (SAW) [11], Weighted Product (WP) [12], Technique for Order Preference by Similarity to Ideal Solution (TOPSIS) dan Analytical Hierarchy Process (AHP) [8].

Dengan melihat beberapa contoh penerapan SPK dalam menyelesaikan masalah pada berbagai bidang, maka penelitian ini bertujuan untuk melakukan pemilihan supplier / pemasok terbaik dengan menerapkan metode-metode dalam SPK. Pemilihan pemasok menjadi masalah penting dalam manajemen rantai pasokan atau yang biasa disebut dengan Supply Chain Management (SCM) dan merupakan masalah pengambilan keputusan multi-kriteria [13]. Pemilihan pemasok saat ini telah menjadi kegiatan yang sangat penting untuk perusahaan, tidak terkecuali pada perusahaan "XYZ" yang menjadi objek pada penelitian ini. Untuk itu, pada penelitian ini akan digunakan beberapa metode dalam SPK untuk mengetahui pemasok mana yang terbaik berdasarkan kriteria-kriteria yang telah ditentukan oleh pengambil keputusan.

Selain itu, penelitian ini akan melakukan perbandingan terhadap 3 metode untuk menyelesaikan masalah pemilihan pemasok tersebut. Hal ini dilakukan untuk mengetahui apakah terdapat perbedaan hasil akhir dari ketiga metode tersebut. Jika terdapat perbedaan, apa yang menyebabkan perbedaan itu dapat terjadi dan pengetahuan apa yang dapat diambil. Metode yang akan dibandingkan pada penelitian ini adalah metode Weighted Sum Model (WSM), Simple Additive Weighting (SAW), Weighted Product (WP). Pada penelitian ini ada dua pertanyaan penelitian, yaitu (i) bagaimana menerapkan metode-metode SPK dalam menyelesaikan masalah pemilihan supplier pada perusahaan "XYZ"? ; (ii) seperti apa hasil perbandingan dari metode SAW, WSM dan WP?

Secara keseluruhan penelitian ini dibagi ke dalam empat bagian, yaitu bagian Pendahuluan pada bagian pertama, tinjauan pustaka dan metodologi penelitian pada bagian kedua, hasil dan pembahasan pada bagian ke tiga, dan yang terakhir bagian keempat yaitu kesimpulan.

\section{Metode Penelitian}

Sebelum memasuki metodologi penelitian dan hasil dari penelitian yang lakukan, terdapat beberapa tinjauan terhadap beberapa teori pendukung yang digunakan pada penelitian ini. Berikut merupakan penjelasan dari beberapa teori pendukung tersebut. 


\subsection{Perusahaan "XYZ"}

Perusahaan "XYZ" merupakan salah satu perusahaan penyedia alat berat. Perusahaan ini dalam menjalankan kegiatan bisnisnya memerlukan supplier / penyedia barang. Banyaknya supplier dengan kekurangan dan kelebihan yang dimiliki tiap-tiap supplier terkadang menyulitkan perusahaan untuk memilih supplier yang tepat. Oleh karena itu, perusahaan "XYZ" memerlukan sebuah metode atau cara-cara tertentu yang terukur dan dapat memudahkan di dalam melakukan pemilihan supplier.

\subsection{Data Alternatif dan Kriteria Penilaian}

Kriteria penilaian yang digunakan dalam penelitian ini dibatasi pada lima kriteria. Kriteria-kriteria tersebut antara lain:

a. Harga, terkait dengan harga barang

b. Kualitas, terkait dengan kualitas barang

c. Pengiriman, terkait dengan pengiriman barang

d. Pelayanan, terkait dengan pelayanan pemasok

e. Pembayaran, terkait dengan kemudahan pembayaran

Ada 5 perusahaan yang akan menjadi alternatif supplier pada penelitian ini. Untuk menjaga kerahasiaan identitas asli dari kelima perusahaan tersebut, maka kelima perusahaan ini akan disebut sebagai Perusahaan "A1", "A2", "A3", "A4" dan "A5".

\subsection{Metode Weighted Sum Model}

Metode Weighted Sum Model (WSM) adalah salah satu metode dalam sistem pendukung keputusan dengan beberapa kriteria yang paling dikenal dan banyak digunakan [1]. Metode ini dapat digambarkan sebagai metode penjumlahan statis. Metode Weight Sum Model merupakan metode yang sangat sederhana dengan hanya beberapa langkah untuk dapat memberikan hasil yang diharapkan, seperti penelitian yang dilakukan oleh [10] terkait dengan penetapan dana alokasi khusus yang terdapat di provinsi Sumatera Utara. Formula yang digunakan pada metode ini dapat dilihat pada persamaan 1.

$A_{i}^{W S M-\text { score }}=\sum_{j=1}^{n} w_{j} a_{i j}$, for $i=1,2,3 \ldots m$.

\subsection{Metode Simple Additive Weighting}

Metode Simple Additive Weighting (SAW) biasa dikenal dengan metode penjumlahan terbobot. Metode ini memiliki kemampuan untuk mengimbangi di antara beberapa kriteria serta perhitungan dalam metode ini cukup sederhana dan dapat dilakukan tanpa bantuan program komputer yang rumit [11].

Tahapan-tahapan dalam metode SAW, antara lain:

1. Menentukan Kriteria Penilaian

2. Berikan bobot untuk tiap kriteria

3. Menentukan alternatif dan nilai alternatif untuk tiap kriteria

4. Matriks Keputusan

5. Normalisasi Matriks

6. Menghitung nilai preferensi untuk tiap-tiap alternatif

7. Nilai preferensi yang terbesar merupakan alternatif yang dijadikan rekomendasi Beberapa formula yang digunakan pada metode ini dapat dilihat pada persamaan 2, 3 dan 4. 


$$
\begin{aligned}
r_{i j} & =\frac{x_{i j}}{\operatorname{Max} x_{i j}} \\
r_{i j} & =\frac{\operatorname{Min} x_{i j}}{x_{i j}} \\
V_{i} & =\sum_{j=1}^{n} w_{j} r_{i j}
\end{aligned}
$$

\subsection{Metode Weighted Product}

Weighted Product (WP) merupakan teknik dalam menyelesaikan suatu permasalahan dalam pengambilan keputusan, teknik ini akan melakukan evaluasi terhadap beberapa alternatif untuk satu set atribut atau kriteria, di mana nantinya setiap atribut yang ada tidak akan saling bergantung antara satu dengan yang lainnya [12]. Jika pada SAW normalisasi dilakukan terhadap matriks keputusan, pada metode ini normalisasi dilakukan dengan menggunakan perkalian untuk menghubungkan rating atribut, dimana rating setiap atribut harus dipangkatkan dulu dengan bobot atribut yang bersangkutan. Formula yang digunakan pada metode ini dapat dilihat pada Persamaan 5.

$S_{i}=\prod_{j=1}^{n} x_{i j}{ }^{w j}$

\subsection{Tahapan Penelitian}

Pada penelitian ini akan dilakukan perbandingan terhadap tiga metode dalam SPK, yaitu WSM, SAW, dan WP dalam menyelesaikan suatu permasalahan. Perbandingan akan dilakukan dengan melakukan penyelesaian terhadap sebuah masalah yang memerlukan sistem pendukung keputusan. Kasus yang diangkat pada penelitian ini adalah pemilihan supplier pada perusahaan "XYZ". Secara keseluruhan, tahapantahapan yang dilakukan pada penelitian ini dapat dilihat pada Gambar 1 .

Dalam melakukan perbandingan terhadap metode Weighted Sum Model (WSM), Simple Additive Weighting (SAW), dan Weighted Product (WP) dilakukan studi literatur dengan mempelajari beberapa penelitian terkait dengan ketiga metode tersebut.

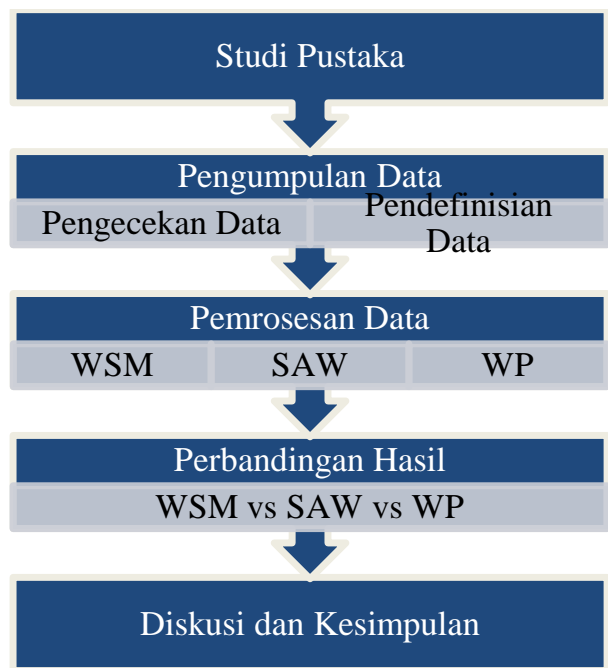

Gambar 1. Tahapan penelitian 
Pada gambar 1, dapat terlihat bahwa penelitian ini diawali dengan melakukan studi literatur, setelah itu dilakukan pengumpulan data, pengecekan dan pendefinisian data yang telah dikumpulkan. Setelah data telah siap, maka dilakukan pemrosesan terhadap data-data tersebut berdasarkan metode Weighted Sum Model (WSM), Simple Additive Weighting (SAW), dan Weighted Product (WP). Data-data yang dimaksud adalah data-data yang terkait dengan kriteria penilaian yang dapat dilihat pada bagian $\mathrm{C}$.

Perbandingan dilakukan terhadap hasil dari tiap-tiap metode yang digunakan sehingga didapat sebuah pengetahuan terhadap hasil dari perbandingan tersebut. Sebelum masuk ke dalam hasil dari penelitian ini, ada beberapa tinjauan teori terhadap hal-hal yang terkait dengan penelitian ini, diantaranya mengenai perusahaan "XYZ", kriteria-kriteria penilaian, Weighted Sum Model (WSM), Simple Additive Weighting (SAW), dan Weighted Product (WP).

\section{Hasil Dan Pembahasan}

Ada beberapa poin yang dibahas pada bagian ini terkait dengan hasil dari penelitian yang dilakukan, antara lain bobot kriteria, nilai alternatif, hasil perhitungan dengan menggunakan metode SAW, hasil perhitungan dengan menggunakan metode WP, hasil perhitungan dengan metode WSM, dan yang terakhir adalah diskusi terkait dengan perbandingan hasil penelitian.

\subsection{Bobot Kriteria}

Pengambil keputusan menetapkan nilai bobot untuk tiap-tiap kriteria yang ada yang telah disebutkan pada bagian 2.2, yaitu:

a. Harga $(\mathrm{H})$ diberikan bobot sebesar $25 \%$

b. Kualitas (K) diberikan bobot sebesar $30 \%$

c. Pengiriman (P) dengan bobot sebesar $15 \%$

d. Pelayanan (L) sebesar $20 \%$

e. Pembayaran (B) sebesar $10 \%$.

\subsection{Tabel Nilai Alternatif}

Untuk mengetahui tabel nilai alternatif, maka sebelumnya harus diketahui dulu, pemberian nilai untuk tiap-tiap kriteria, antara lain:

a. Harga.

Untuk harga dengan ketentuan nilai sebagai berikut:

1: Harga murah

2: Harga normal

3: Harga mahal

b. Kualitas.

Untuk kualitas dengan ketentuan nilai sebagai berikut:

1: Sangat berkualitas

2: Cukup berkualitas

3: Tidak berkualitas

c. Pengiriman.

Untuk pengiriman dengan ketentuan nilai sebagai berikut:

1: Cepat

2: Lama

3: Sangat Lama

d. Pelayanan. 
Untuk pelayanan dengan ketentuan nilai sebagai berikut:

1: Sangat Baik

2: Baik

3: Tidak Baik

e. Pembayaran.

Untuk pembayaran dengan ketentuan nilai sebagai berikut:

1: Sangat Mudah

2: Mudah

3: Sulit.

Berdasarkan nilai-nilai tersebut dan data-data yang telah dikumpul, dicek dan didefinisikan, maka dituangkan ke dalam tabel nilai alternatif yang dapat dilihat pada Tabel 1 .

Tabel 1. Nilai Alternatif untuk Tiap Kriteria

\begin{tabular}{|c|c|c|c|c|c|}
\hline \multirow{2}{*}{ Alternatif } & \multicolumn{5}{|c|}{ Kriteria } \\
\cline { 2 - 6 } & $\boldsymbol{H}$ & $\boldsymbol{K}$ & $\boldsymbol{P}$ & $\boldsymbol{L}$ & $\boldsymbol{B}$ \\
\hline A1 & 2 & 2 & 1 & 2 & 2 \\
\hline A2 & 1 & 2 & 1 & 1 & 1 \\
\hline A3 & 1 & 1 & 2 & 3 & 2 \\
\hline A4 & 3 & 1 & 2 & 1 & 1 \\
\hline A5 & 3 & 1 & 1 & 1 & 1 \\
\hline
\end{tabular}

\subsection{Hasil Perhitungan SAW}

Dengan menggunakan tabel 1, maka langkah selanjutnya dalam perhitungan SAW adalah melakukan normalisasi matriks dengan menggunakan persamaan 2 jika kriteria keuntungan, dan persamaan 3 jika termasuk kriteria biaya. Berdasarkan tabel 1 dan penjelasan yang terdapat pada bagian 3.2 maka dapat disimpulkan bahwa semua kriteria termasuk ke dalam kriteria biaya. Dengan menggunakan persamaan 3, maka perhitungan normalisasi dapat dijabarkan sebagai contoh berikut:

- Untuk Alternatif A1 dan kriteria $\mathrm{H}\left(\mathrm{R}_{11}\right)$

$\mathrm{R}_{11}=\frac{\min \{2 ; 1 ; 1 ; 3 ; 3\}}{2}=\frac{1}{2}=0.5$

Perhitungan tersebut terus dilakukan untuk semua alternatif pada semua kriteria, sehingga hasilnya dapat dilihat pada Tabel 2.

Tabel 2. Hasil Normalisasi

\begin{tabular}{|c|c|c|c|c|c|}
\hline Alternatif & H & K & P & L & B \\
\hline A1 & 0.5 & 0.5 & 1 & 0.5 & 0.5 \\
\hline A2 & 1 & 0.5 & 1 & 1 & 1 \\
\hline A3 & 1 & 1 & 0.5 & 0.333333 & 0.5 \\
\hline A4 & 0.333333 & 1 & 0.5 & 1 & 1 \\
\hline A5 & 0.333333 & 1 & 1 & 1 & 1 \\
\hline
\end{tabular}

Setelah melakukan normalisasi, langkah selanjutnya adalah melakukan perangkingan dengan menggunakan Persamaan 4, yaitu dengan menjumlahkan hasil dari perkalian antara nilai alternatif dari setiap kriteria dengan bobot tiap-tiap kriteria (w) yang telah dijelaskan pada Bagian 3.1. Contoh perhitungannya adalah sebagai berikut:

- $\mathrm{V} 1=(0.5 * 0.25)+(0.5 * 0.3)+(1 * 0.15)+(0.5 * 0.2)+(0.5 * 1)=0.575$ 
Perhitungan dilakukan untuk semua alternatif, sehingga hasilnya dapat terlihat pada tabel 3.

Tabel 3. Hasil Perangkingan
\begin{tabular}{|c|c|}
\hline V & Nilai \\
\hline V1 & 0.575 \\
\hline V2 & 0.875 \\
\hline V3 & 0.741667 \\
\hline V4 & 0.725 \\
\hline V5 & 0.8 \\
\hline
\end{tabular}

Berdasarkan pada tabel 3, tersebut dapat dilihat bahwa nilai V2 menunjukan nilai yang terbesar, itu artinya bahwa alternatif A2-lah yang dipilih sebagai supplier terbaik. Secara keseluruhan urutan alternatif dari nilai yang terbesar adalah A2, A5, A3, A4, dan yang terkecil A1.

\subsection{Hasil Perhitungan WP}

Untuk melakukan perhitungan dengan metode WP maka akan digunakan persamaan nomor 5. Nilai "w" adalah nilai yang mewakili bobot tiap-tiap kriteria yang telah ditentukan. Dimana nilai "w" adalah pangkat bernilai negatif untuk atribut atau kriteria biaya dan akan bernilai positif jika merupakan kriteria atau atribut keuntungan. Sedangkan, nilai " $x$ " adalah nilai alternatif pada tiap-tiap kriteria, seperti yang terdapat pada Tabel 1. Langkah selanjutnya yang harus dilakukan pada perhitungan metode WP adalah menghitung nilai vektor S. Berikut adalah contoh perhitungan dari vektor $S$ tersebut.

- $\mathrm{S}_{1}=\left(2^{-0.25}\right)\left(2^{-0.3}\right)\left(1^{-0.15}\right)\left(2^{-0.2}\right)\left(2^{-0.1}\right)=0.554785$

Perhitungan tersebut dilakukan pada semua alternatif yang ada atau dengan kata lain hingga mendapatkan nilai vektor $\mathrm{S}_{5}$. Adapun hasil perhitungan tersebut dapat dilihat pada Tabel 4.

Tabel 4. Hasil Vektor $\mathrm{S}$

\begin{tabular}{|c|c|}
\hline $\mathbf{S}$ & Nilai \\
\hline $\mathbf{S}_{\mathbf{1}}$ & 0.554785 \\
\hline $\mathbf{S}_{\mathbf{2}}$ & 0.840896 \\
\hline $\mathbf{S}_{\mathbf{3}}$ & 0.675023 \\
\hline $\mathbf{S}_{\mathbf{4}}$ & 0.6482 \\
\hline $\mathbf{S}_{\mathbf{5}}$ & 0.719223 \\
\hline
\end{tabular}

Langkah terakhir adalah melakukan perangkingan dengan melakukan perhitungan nilai $\mathrm{V}$ berdasarkan nilai dari vektor $\mathrm{S}$. Dimana nilai dari sebuah vektor $\mathrm{S}_{\mathrm{i}}$ akan dibagi dengan total dari seluruh vektor $\mathrm{S}$.
a) $\mathrm{V}_{1}=0.554785 /(0.554785+0.840896+0.675023+0.6428+0.719223)=0.161362$
b) $\mathrm{V}_{2}=0.840896 /(0.554785+0.840896+0.675023+0.6428+0.719223)=\mathbf{0 . 2 4 4 5 8}$
c) $\mathrm{V}_{3}=0.675023 /(0.554785+0.840896+0.675023+0.6428+0.719223)=0.196334$
d) $\mathrm{V}_{4}=0.6482 /(0.554785+0.840896+0.675023+0.6428+0.719223)=0.188533$
e) $\mathrm{V}_{5}=0.719223 /(0.554785+0.840896+0.675023+0.6428+0.719223)=0.20919$

Berdasarkan perhitungan vektor $\mathrm{V}$ tersebut maka dapat disimpulkan bahwa nilai V2 atau alternatif supplier A2-lah yang memiliki nilai terbesar. Sehingga jika diurutkan dari nilai terbesar hingga terkecil adalah alternatif A2, A5, A3, A4 dan A1. 


\subsection{Hasil Perhitungan WSM}

Perhitungan dengan metode WSM dilakukan dengan mengacu pada persamaan 1 dan penelitian yang dilakukan oleh [10]. Kemudian, dengan menggunakan ketentuan yang terdapat pada Bagian 3.1, 3.2 dan Tabel 1, dilakukan perhitungan untuk menentukan WSM-Score untuk tiap-tiap alternatif dengan menggunakan rumus seperti yang terdapat pada Persamaan 1. Perhitungan dilakukan dengan melakukan penjumlahan terhadap semua hasil perkalian dari setiap nilai alternatif pada tiap-tiap kriteria dengan bobot dari tiap kriteria tersebut. Berikut merupakan contoh dan hasil perhitungan dengan menggunakan persamaan 1 tersebut.
a) $\mathrm{A} 1=(2 * 0.3)+(2 * 0.25)+(1 * 0.15)+(2 * 0.2)+(2 * 0.1)=1.65$
b) $\mathrm{A} 2=(1 * 0.3)+(2 * 0.25)+(1 * 0.15)+(1 * 0.2)+(1 * 0.1)=1.15$
c) $\mathrm{A} 3=(1 * 0.3)+(1 * 0.25)+(2 * 0.15)+(3 * 0.2)+(2 * 0.1)=1.45$
d) $\mathrm{A} 4=(3 * 0.3)+(1 * 0.25)+(2 * 0.15)+(1 * 0.2)+(1 * 0.1)=1.65$
e) $\mathrm{A} 5=(3 * 0.3)+(1 * 0.25)+(1 * 0.15)+(1 * 0.2)+(1 * 0.1)=1.5$

Berdasarkan hasil dari perhitungan tersebut, dilakukan pengurutan berdasarkan jumlah terbesar hingga terkecil sehingga didapatkan hasil pengurutan sebagai berikut A1, A4, A3, A5, A2. Terlihat bahwa Alternatif A1 dan A4 memiliki nilai yang sama yaitu sebesar 1.65. Sehingga kedua Alternatif tersebut dapat dijadikan acuan dalam memilih supplier / pemasok bagi perusahaan. Sedangkan, alternatif A2 memiliki nilai terkecil yaitu sebesar 1.15. Artinya, dengan menggunakan metode WSM alternatif A2 sangat tidak dianjurkan untuk dipilih menjadi pemasok bagi perusahaan.

\subsection{Diskusi}

Berdasarkan hasil perhitungan yang telah dijelaskan pada bagian 3.3, 3.4 dan 3.5, maka perbedaan dari tiap-tiap perhitungan tersebut dapat dilihat pada Gambar 2 .

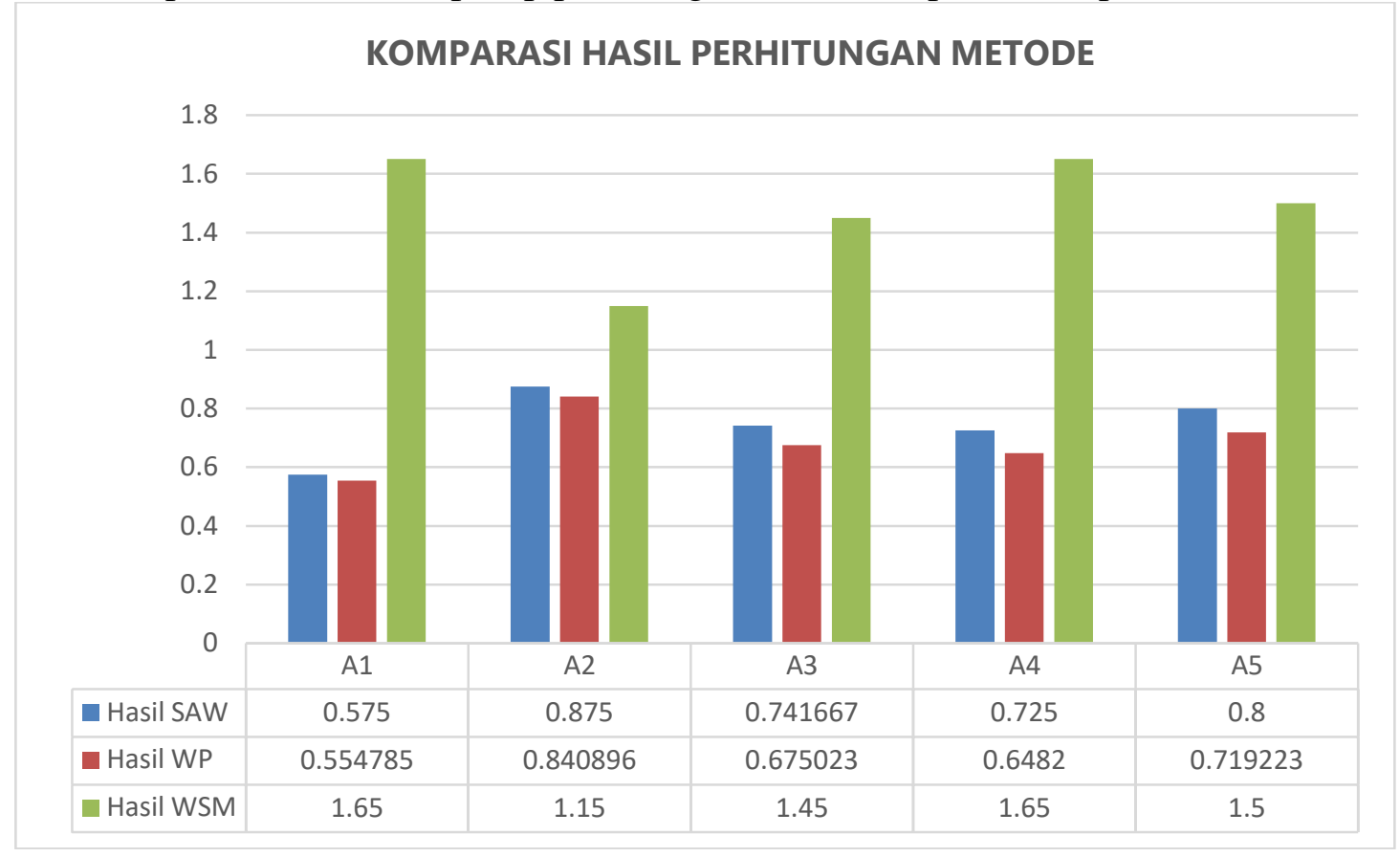

Gambar 2. Komparasi Hasil Perhitungan

Pada Gambar 2 terlihat hasil akhir dari perhitungan tiap-tiap metode yang dilakukan untuk memilih alternatif supplier terbaik untuk perusahaan. Pada Gambar 2, dapat dilihat bahwa hasil perhitungan antara metode SAW dan WP terdapat kesamaan 
dimana Alternatif A2 memiliki nilai yang terbesar dan alternatif A1 memiliki nilai yang terkecil. Walaupun memiliki kesamaan dalam urutan perangkingan, tetapi masih terdapat perbedaan yaitu untuk besaran nominal dari tiap dari alternatif, dimana nominal angka dengan menggunakan metode SAW cenderung memiliki nilai yang lebih besar dibanding dengan hasil menggunakan WP. Untuk hasil dengan metode WSM sangat jauh berbeda dan berbanding terbalik dengan dua metode sebelumnya, bahkan terlihat pada Gambar 2 terdapat selisih yang cukup jauh antara metode tersebut dengan dua metode lainnya. Jika pada WP dan SAW alternatif terbaik jatuh pada alternatif A2, maka pada WSM alternatif tersebut justru menjadi alternatif terburuk dengan nilai paling rendah. Begitu juga sebaliknya, jika pada WP dan SAW alternatif A1 menjadi alternatif dengan nilai terendah, maka pada WSM alternatif tersebut memiliki nilai tertinggi. Perbedaan yang mencolok ini dapat terjadi karena perhitungan pada metode WSM tidak ada melalui proses normalisasi terhadap nilai alternatif pada tiap-tiap kriteria seperti yang terdapat pada metode SAW maupun metode WP. Dengan tidak adanya proses normalisasi tersebut dapat membuat hasil dari metode WSM menjadi bias, kurang optimal dan berbeda dengan metode lainnya.

\section{Kesimpulan}

Berdasarkan beberapa penjelasan khususnya pada bagian hasil perhitungan metode dan diskusi dapat disimpulkan bahwa secara keseluruhan perhitungan dengan menggunakan metode-metode tersebut menghasilkan urutan perangkingan yang sama, khususnya untuk metode SAW dan WP. Yang menjadi menarik perhatian adalah meskipun urutannya sama tetapi terdapat perbedaan yang signifikan dari sisi nilai akhir yang dihasilkan dimana nilai SAW memiliki nilai akhir untuk tiap alternatif yang lebih besar jika dibandingkan metode WP. Ini dapat disebabkan karena perbedaan cara perhitungan khususnya pada proses normalisasi untuk tiap-tiap metode. Di sisi yang lain perhitungan dengan menggunakan WSM sangat jauh berbeda dengan dua metode sebelumnya, hal ini dikarenakan tidak adanya proses normalisasi. Oleh karena itu, dalam usaha untuk menyelesaikan suatu permasalahan terkait dengan pengambilan keputusan yang sederhana yang mana salah satunya terkait dengan pemilihan supplier, metode SAW dan WP dapat dipilih sebagai rujukan utama dibandingkan dengan metode WSM.

Berdasarkan hasil penelitian, maka terdapat beberapa saran yang dapat ditindaklanjuti untuk penelitian dimasa yang akan datang. Penelitian dimasa yang akan datang dapat membuat perbandingan berbagai metode dalam sistem pendukung keputusan yang belum pernah dibandingkan sebelumnya. Diperlukan adanya sebuah aplikasi sistem pendukung keputusan yang dirancang untuk lebih memudahkan proses pengambilan keputusan didalam sebuah perusahaan. Yang terakhir dapat dilakukan penelitian untuk mengetahui state of the art yang lebih komprehensif terhadap implementasi berbagai metode sistem pendukung keputusan, khususnya di Indonesia.

\section{Ucapan Terima Kasih}

Terima kasih yang sebesar-besar penulis sampaikan kepada pihak-pihak yang terlibat dalam penyusunan artikel ini, baik yang secara langsung maupun tidak langsung. Khususnya kepada Saudara Muhammad Fadlan yang telah membantu dalam penyelesaian artikel ini hingga proses publikasi. 


\section{Daftar Pustaka}

[1] H. O. Alanazi, A. H. Abdullah, and M. Larbani, "Dynamic Weighted Sum MultiCriteria Decision Making: Mathematical Model," Int. J. Math. Stat. Invent., vol. 1, no. 2, pp. 2013-16, 2013.

[2] Y. J. Wang, "A fuzzy multi-criteria decision-making model based on simple additive weighting method and relative preference relation," Appl. Soft Comput. J., vol. 30, pp. 412-420, 2015.

[3] D. L. Kurniasih, "Sistem Pendukung Keputusan Pemilihan Laptop Dengan Metode Topsis," Pelita Inform. Budi Darma, vol. III, no. April, pp. 6-13, 2013.

[4] M. Avvenuti, S. Cresci, A. Marchetti, and C. Meletti, "EARS ( Earthquake Alert and Report System ): a Real Time Decision Support System for Earthquake Crisis Management," pp. 1749-1758, 2013.

[5] P. V. Gorsevski, S. C. Cathcart, G. Mirzaei, M. M. Jamali, X. Ye, and E. Gomezdelcampo, "A group-based spatial decision support system for wind farm site selection in Northwest Ohio," Energy Policy, vol. 55, pp. 374-385, 2013.

[6] A. Kusumaningrum, "PENERAPAN SIMPLE ADDITIVE WEIGHTING AND LOCATION QUOTIENT UNTUK MENENTUKAN LOKASI PENYEBARAN TERNAK (Studi Kasus: Kabupaten Brebes)," in SENATIK STT Adisutjipto Yogyakarta, 2013, vol. 1, pp. 108-119.

[7] O. W. Samuel, G. M. Asogbon, A. K. Sangaiah, P. Fang, and G. Li, "An integrated decision support system based on ANN and Fuzzy_AHP for heart failure risk prediction," Expert Syst. Appl., vol. 68, pp. 163-172, 2017.

[8] M. Fadlan, Muhammad, and Hadriansa, "Terapan Kombinasi Metode Topsis dan Analytical Hierarchy Process Pada Perekomendasian Penerima Beasiswa Peningkatan Prestasi Akademik (studi kasus pada STMIK PPKIA Tarakanita Rahmawati)," J. SIMETRIS, vol. 8, no. 2, pp. 663-670, 2017.

[9] M. Fadlan and D. Kurniawan, "Rekayasa Aplikasi Pemilihan Anggota Peserta Lomba Cerdas Cermat Menggunakan Metode Simple Additive Weighting (SAW)," in PROSIDING SNIT SEMINAR NASIONAL INOVASI \& TREN, 2014, pp. A213-A216.

[10] D. Handoko, M. Mesran, S. D. Nasution, Y. Yuhandri, and H. Nurdiyanto, "Application Of Weight Sum Model (WSM) In Determining Special Allocation Funds Recipients," IJICS (International J. Informatics Comput. Sci., vol. 1, no. 2, pp. 31-35, 2017.

[11] M. Velasquez and P. T. Hester, "An Analysis of Multi-Criteria Decision Making Methods," Int. J. Oper. Res., vol. 10, no. 2, pp. 56-66, 2013.

[12] D. M. Khairina, M. R. Asrian, and H. R. Hatta, "Decision support system for new employee recruitment using weighted product method," Proc. - $20163 \mathrm{rd}$ Int. Conf. Inf. Technol. Comput. Electr. Eng. ICITACEE 2016, pp. 297-301, 2017.

[13] X. Deng, Y. Hu, Y. Deng, and S. Mahadevan, "Supplier selection using AHP methodology extended by D numbers," Expert Syst. Appl., vol. 41, no. 1, pp. 156-167, 2014. 